\title{
RANCANG BANGUN SISTEM FERTIGASI DENGAN MENGGUNAKAN VENTURIMETER
}

\section{THE FERTIGATION SYSTEM DESIGN BY USING VENTUREMETERS}

\author{
Budianto Lanya ${ }^{1 \bowtie}$ Prabowo Agung Laksono $^{1}$, M. Amin ${ }^{1}$, Ridwan ${ }^{1}$ \\ ${ }^{1}$ Jurusan Teknik'Pertanian, Fakultas Pertanian, Universitas Lampung \\ ${ }^{\square}$ Komunikasi penulis, email : budianto.lanya@fp.unila.ac.id \\ DOI:http://dx.doi.org/10.23960/jtep-lv9i2.122-130 \\ Naskah ini diterima pada 16 Maret 2018; revisi pada 20 Juni 2020; \\ disetujui untuk dipublikasikan pada 20 Juni 2020
}

\begin{abstract}
Farmers in Indonesia have not yet applied fertigation technology using venturimeters which can facilitate the work offarmers to water and fertilize plants. This study aims to make a fertigation system tool using a venturimeter, determine the discharge from the system circuit, and the discharge of nutrient output and the ratio of dissolved nutrients. Fertilizer tool design using a PVC pipe and two parallel mounted venturimeters, with the size of one inch. The test was carried out with three variations of the vertical distance of the nutrient fluid to the venturimeter $44 \mathrm{~cm}, 52 \mathrm{~cm}$ and $79 \mathrm{~cm}$. This fertigation tool functions to produce a series of irrigation systems $0.778 \mathrm{l} / \mathrm{s}$ with pressure on the main pipe M1 = 1.90 bar, pressure before passing venturi 0.9 bar (on M2 and M3), after veventuri 0.45 bar (on M4 and M5) and in the main pipe output M6 = 1.69 bar. Nutrient discharge was successively $5.19 \mathrm{ml}$ $/ \mathrm{s}, 4.31 \mathrm{ml} / \mathrm{s}$ and $2.13 \mathrm{ml} / \mathrm{s}$, until the ratio of nutrition to irrigation water was obtained $0.67 \%, 0.55 \%$ and $0.27 \%(V / V)$ ). Nutrient ratio settings can be changed by adjusting the vertical suction distance between the liquid surface on the nutrient container with a venturimeter, the greater the nutrient suction distance, the smaller the ratio of nutrients to irrigation water.
\end{abstract}

Keywords : fertigation, fertilizer, irrigation, venturimeter

\begin{abstract}
ABSTRAK
Petani di Indonesia belum banyak menerapkan teknologi fertigasi yang menggunakan venturimeter yang dapat mempermudah pekerjaan para petani melakukan penyiraman sekaligus memupuk tanaman. Penelitian ini bertujuan membuat alat sistem fertigasi dengan menggunakan venturimeter, mengetahui debit dari rangkaian sistem, dan debit keluaran nutrisi dan rasio nutrisi terlarut. Telah dihasilkan rancangan alat fertigasi menggunakan pipa PVC dan dua venturimeter dipasang paralel, dengan ukuran satu inch. Pengujian dilakukan dengan tiga variasi jarak vertikal cairan nutrisi terhadap venturimeter $44 \mathrm{~cm}, 52 \mathrm{~cm}$, dan $79 \mathrm{~cm}$. Alat fertigasi ini berfungsi menghasilkan debit rangkaian sistem irigasi 0,778 l/s dengan tekanan pada pipa utama M1=1,90 bar, tekanan sebelum melewati venturi 0,9 bar (pada M2 dan M3), sesudah veventuri 0,45 bar (pada M4 dan M5) dan di pipa utama keluaran M6=1,69 bar. Debit nutrisi terhisap berturutan 5,19 ml/s, 4,31 ml/s dan 2,13 ml/s, hingga diperoleh rasio nutrisi terhadap air irigasi 0,67 \%, 0,55 \% dan 0,27 \% (V/V). Pengaturan rasio nutrisi dapat diubah dengan mengatur jarak hisap vertikal antara permukaan cairan pada wadah nutrisi dengan venturimeter, semakin besar jarak hisap nutrisi maka semakin kesil rasio nutrisi terhadap air irigasi.
\end{abstract}

Kata Kunci : fertigasi, irigasi, pemupukan, venturimeter

\section{PENDAHULUAN}

Aplikasi teknologi irigasi bertekanan baik dengan sprinkler maupun tetes, mempunyai efisiensi irigasi lebih tinggi dibanding irigasi permukaan. Irigasi bertekanan lebih tepat untuk daerahdaerah yang relatif kering. Sistem irigasi ini menggunakan air tanah dan pompa memerlukan biaya relatif mahal maka implementasinya diarahkan kepada tanaman bernilai ekonomi tinggi (Direktorat Pengelolaan Air, 2010). Sistem pengairan tanaman dan pemupukan yang diberikan sekaligus melalui irigasi tetes disebut sistem fertigasi. 
Pupuk adalah material yang pada umumnya ditambahkan di dalam media tanam atau tanaman untuk mencukupi kebutuhan hara yang sangat dibutuhkan oleh tanaman sehingga tanaman dapat berproduksi dengan baik (Djunaedi dan Wicaksono, 2013). Material pupuk dapat berupa bahan-bahan organik maupun mineral. Pupuk berbeda dengan suplemen, pupuk mengandung bahan baku yang diperlukan oleh tanaman untuk pertumbuhan dan perkembangan tanaman, sementara suplemen seperti hormon tumbuhan untuk membantu kelancaran metabolisme (Saputro dkk., 2017). Dalam pemberian pupuk perlu diperhatikan kebutuhan tanaman tersebut, pemupukan dan penyiraman pada umumnya dilakukan secara bersamaan agar pencampuran air dan pupuk/nutrisi dapat tercampur secara merata.

Sistem fertigasi adalah metode pemberian nutrisi atau unsur hara bagi tanaman melalui irigasi sprinkler, tetes dan metode penyiraman lainnya (Saputri, 2009). Pemberian nutrisi atau unsur hara diberikan bersamaan dengan aliran irigasi (debit air irigasi) melalui jaringan perpipaan. Venturimeter terdiri atas pipa yang memiliki luas penampang berbeda, masing-masing memiliki tabung di bagian atas pipa untuk mengetahui tekanan pipa (Al-Ayubi, 2015). Pipa merupakan saluran tertutup yang digunakan sebagai sarana pengaliran fluida. Pipa PVC jenis ini pada umumnya digunakan untuk mengalirkan fluida dengan korosi aktif.

Naswir dkk. (2009) Telah merancang sistem fertigasi mikro yang dibangun dari komponen lokal berupa penetes dari pipa plastik transparan berdiameter $0.5 \mathrm{~mm}$ dan pipa lateral PVC hose $5 / 16$ inci telah dapat beroperasi dengan baik. Aplikasi sistem fertigasi mikro dengan memanfaatkan uriferm sebagai pupuk cair memperlihatkan pertumbuhan dan penyebaran perakaran tanaman cabai lebih baik, dan dapat menghemat pemakaian air $49.48 \%$ serta meningkatkan produksi tanaman cabai sebesar $61.23 \%$ jika dibandingkan dengan sistem siram. Sistem fertigasi mikro dengan penggunaan uriferm layak diaplikasikan dalam budi daya tanaman cabai.

Sistem fertigasi dengan venturimeter masih memerlukan kajian untuk dapat mendalami sistem kerja alat dan performanya. Perancangan alat dapat dipilih menggunakan bahan-bahan seperti PVC hingga dapat dibuat dengan biaya murah. Dengan alat fertigasi yang menggunakan venturimeter yang dapat melakukan penyiraman dan pemupukan dalam waktu yang bersamaan akan dapat meringankan kerja petani. Alat fertigasi dengan venturimeter dapat memberikan jumlah air penyiraman dan dosis pupuk tertentu yang seragam disesuaikan dengan kebutuhan tanaman. Teknik penyiraman dang pemupukan secara bersamaan merupakan bagian dari sistem irigasi otomatis untuk penyediaan air dan pupuk sesuai dengan yang diinginkan (Saptomo dkk, 2012). Oleh karena itu diperlukan penelitian pembuatan rancangan alat fertigasi dengan venturimeter dan menguji kinereja alat hasil penelitian.

\section{BAHAN DAN METODA}

Penelitian ini dilakukan mulai bulan April 2017 bertempat di Laboratorium Daya dan Alat Mekanisasi Pertanian (DAMP), Jurusan Teknik Pertanian Fakultas Pertanian Universitas Lampung. Pembuatan alat dilakukan pada bulan Juli 2017 sampai dengan Agustus 2017. Alat-alat yang digunakan dalam penelitian ini gergaji potong, gelas ukur, disk filter ukuran 1 inchi, bor, venturimeter ukuran 1 inchi, gunting, meteran, paku, manometer tekanan $10 \mathrm{bar}$, flow controller dan amplas. Bahan-bahan yang digunakan dalam penelitian ini adalah pipa PVC ukuran 1 inchi, sambungan pipa T, sambungan pipa L, wadah larutan nutrisi, selang plastik polyethylen (PE), lem pipa, stop kran, kayu reng, kayu kaso.

\subsection{Prosedur Penelitian}

Prosedur penelitian meliputi membuat rancangan atau desain dengan gambar, menyiapkan bahan dan alat yang dibutuhkan, perakitan, pengujian pendahuluan, perbaikan, pengujian dan pengambilan data serta analisis data.

\subsection{Kriteria Desain}

1) Alat fertigasi menggunakan venturimeter untuk menghasilkan campuran air dan pupuk yang diperlukan untuk penyiraman dan pemupukan tanaman. 
2) Alat fertigasi dapat mengatur banyaknya larutan nutrisi atau dosis pupuk untuk tanaman dengan mengatur besarnya tekanan dan tinggi isap penempatan larutan.

\subsection{Rancangan Alat}

Desain alat sistem fertigasi menggunakan dua venturimeter yang dirangkai seri dan atau dirangkai pararel. Rancangan alat fertigasi dengan dua venturimeter yang dirangkai seri, supplai debit air dari pompa melalui salura pipa utama yang dipasang kran, manometer M1, dan disk filter, lalu bercabang ke pipa lateral 1 dan pipa lateral 2. Pada setiap pipa lateral dipasang venturimeter untuk pengambilan cairan nutrisi, selanjutnya ke pipa keluaran. Kemudian air

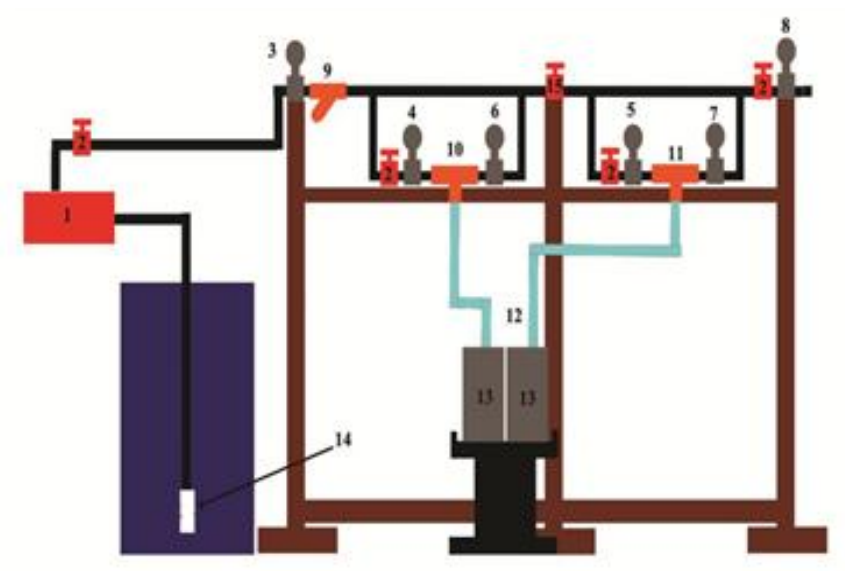

(a)
1. Pompa
2. Kran
3. Manometer (M1)
4. Manometer (M2)
5. Manometer (M3)

7. Manometer (M5)

8. Manometer (M6)

9. Disk filter

10. Venturimeter 1 diukur tekananannya dengan manometer, setelah itu aliran pipa terbagi menjadi 2 aliran, lalu laju aliran air diatur oleh kran dengan bukaan $30^{\circ}, 45^{\circ}, 60^{\circ}$, dan $90^{\circ}$, sehingga laju air dapat dikendalikan dan air masuk ke dalam venturimeter. Setelah air berada di dalam venturimeter, tekanan air menarik larutan nutrisi dari wadah larutan nutrisi. Laju pencampurannya disalurkan kembali ke pipa yang diukur oleh manometer. Rancangan struktural rangkaian seri dapat dilihat pada Gambar 1a, sedangkan Rancangan struktural rangkaian pararel dapat dilihat pada Gambar 1b (Madhu, dan Bheemarao, 2016). Pada rangkaian paralel terdapat pipa bypass, dengan peletakan diantara kedua pipa lateral, dapat dilihat pada Gambar 2.

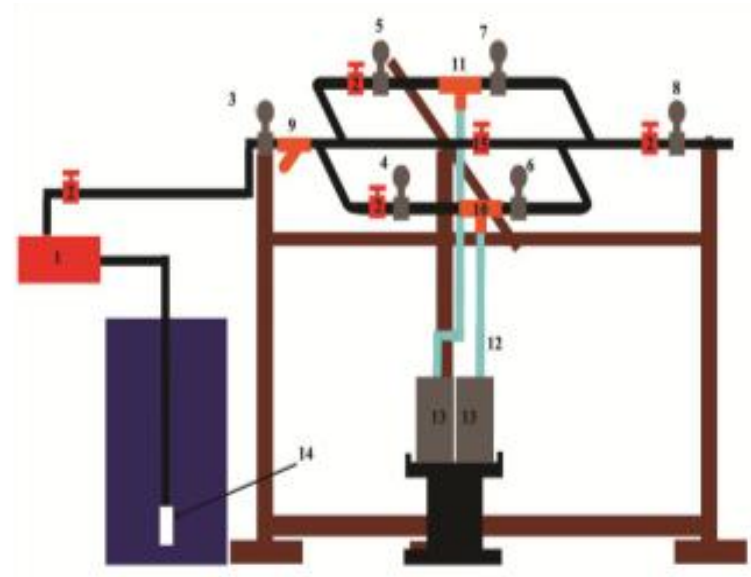

(b)

11. Venturimeter 2
12. Selang air
13. Wadah air
14. Klep air
15. Kran by pass

16. Lateral 1

17. Lateral 2

Gambar 1. Rancangan Struktural Alat Fertigasi Rangkaian (a) Seri dan (b) Paralel

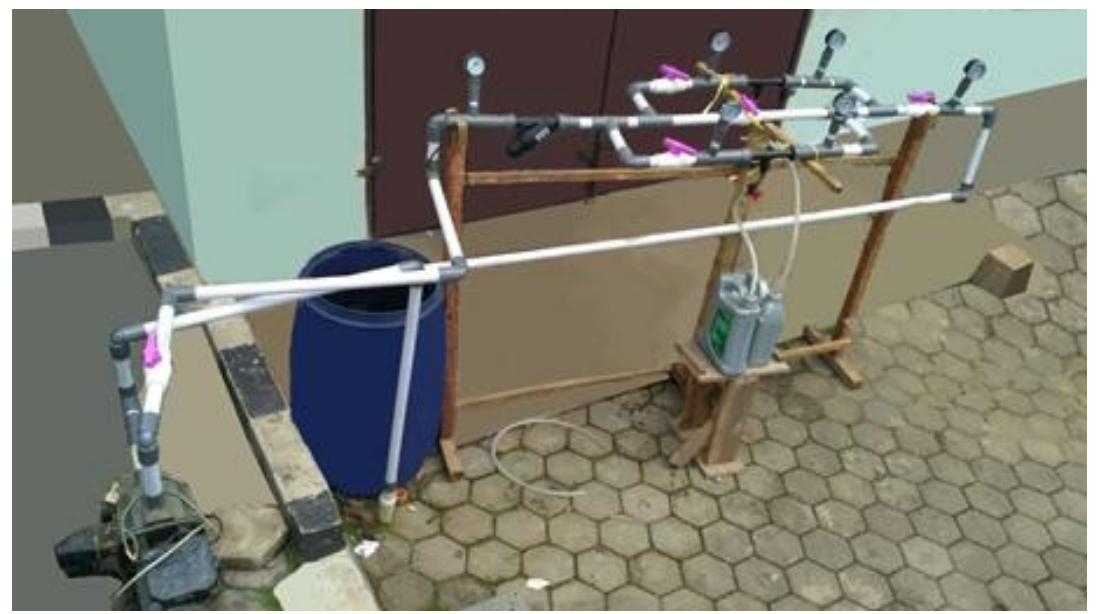

Gambar 2. Alat Fertigasi Hasil Penelitian Menggunakan Dua Venturimeter Dirangkai Paralel 


\subsection{Mekanisme Kerja}

Pada percobaan penelitian ini mekanisme kerja dari tersebut yakni sebagai berikut :

1) Pada percobaan ini air yang tersedia dalam wadah akan dialirkan melalui pompa air yang diukur oleh manometer (M1), dan akan disaring dengan disk filter, setelah itu air akan dialirkan menjadi 2 bagian dengan sistem by pass (Gambar $1 \mathrm{~b}$ ) ditengah pipa utama.

2) Air yang sudah terbagi kebagian lainnya akan dialirkan ke dalam venturimeter namun sebelumnya aliran akan diatur tekanannya dengan kran bukaan $30^{\circ}, 45^{\circ}, 60^{\circ}$, dan $90^{\circ}$, lalu tekanan tersebut diukur oleh manometer (M2) dan (M3) untuk mengukur tekanan sebelum air masuk ke dalam venturimeter.

3) Di dalam venturimeter air akan menarik larutan nutrisi dari wadah larutan nutrisi (drigen) melalui selang yang sudah terhubung.

4) Setelah air menarik larutan nutrisi di dalam venturimeter air akan keluar untuk diukur tekanannya oleh manometer (M4) dan (M5).

5) Setelah air yang telah tercampur oleh larutan nutrisi, air akan kembali dialirkan ke pipa utama dan diukur kembali dengan manometer (M6), setelah itu air dialirkan kembali ke wadah air.

\subsection{Uji Kinerja Alat}

Pengujian komponen alat ini diamati untuk memastikan bahwa setiap komponen diharapkan bekerja dengan baik. Setelah semua komponen alat bekerja dengan baik langkah selanjutnya adalah pengujian alat fertigasi venturimeter dan pengukuran tekanan pada manometer. Faktor-faktornya adalah tekanan air yang keluar dari pompa air, mengatur bukaan kran pada jaringan perpipaan dengan bukaan $30^{\circ}, 45^{\circ}, 60^{\circ}, 90^{\circ}$ yang dilakukan pada kran di lateral 1 dan lateral 2, dan larutan nutrisi yang akan teralirkan.

\subsection{Parameter Alat Sistem Fertigasi Venturi}

Parameter yang diukur yaitu tekanan yang dihasilkan pompa, mengatur bukaan kran pada lateral 1 dan lateral 2, dan mengamati kurangnya larutan yang ada dalam wadah drigen yang sudah disiapkan. Prosedur ini menggunakan stopwatch untuk mengukur larutan yang terangkut. Stopwatch diatur terlebih dahulu dengan waktu 3 menit, dalam waktu 3 menit berapa ml larutan yang teralirkan. Rancangan ini akan dilakukan pengukuran debit total, dan laju nutrisi terangkut.

$$
\text { Debit }=\frac{\text { Volume }}{\text { Waktu }}
$$

\section{HASIL DAN PEMBAHASAN}

\subsection{Prototype Alat}

Alat sistem fertigasi dengan menggunakan dua venturimeter dirangkai paralel telah dibuat mempunyai dimensi panjang $\mathrm{x}$ lebar $\mathrm{x}$ tinggi sebesar $220 \mathrm{~cm}$ x $78 \mathrm{~cm}$ x $131 \mathrm{~cm}$ (Gambar 2). Alat ini menggunakan jet-pump dapat menambahkan larutan nutrisi ke dalam air irigasi sebanyak 2,13 - 5,19 ml/s. Semula penelitian direncanakan membuat dua tipe alat fertigasi yang dirangkai seri dan paralel. Pembuatan alat fertigasi rangkaian seri yang mengacu pada rancangan Gambar 1, venturi pada lateral 2 tidak dapat menghisap cairan nutrisi. Hal ini kemungkinan disebabkan venturi 2 tidak mendapatkan selisih tekanan yang cukup untuk menghisp cairan nutrisi. Pembuatan alat fertigasi rangkaian paralel yang mengacu pada rancangan Gambar 2 berhasil dan berfungsi baik oleh karena itu hasil penelitian fokus untuk menganalisis alat ini.

\subsection{Dimensi Alat Fertigasi}

Setelah dilakukan proses perancangan alat maka diperoleh ukuran alat yang terdiri dari kerangka penopang, dan ukuran rangkaian alat. Panjang kerangka penopang didapatkan $171 \mathrm{~cm}$, lebar atas $78 \mathrm{~cm}$, lebar bawah $113 \mathrm{~cm}$ dan tinggi 131 $\mathrm{cm}$. Ukuran rangkaian alat antara lain: tinggi pipa hisap $109 \mathrm{~cm}$ dan tinggi pipa ke manometer 11 $\mathrm{cm}$, panjang pipa pompa $66 \mathrm{~cm}$, panjang pipa utama $168 \mathrm{~cm}$, dan panjang lateral 1 dan lateral 2 adalah $80 \mathrm{~cm}$. Dimensi alat fertigasi hasil rancangan dapat dilihat pada Tabel 1 .

\subsection{Analisis Teknik}

\subsubsection{Kapasitas Alat}

Alat fertigasi dengan dua venturimeter dirangkai paralel memiliki panjang total $220 \mathrm{~cm}$ dengan lebar $78 \mathrm{~cm}$ tekanan yang diperlukan pada alat ini adalah 2 bar dengan pipa berukuran 1 inchi. Dengan menggunakan pompa jenis jet-pump seri PC-375 BIT yang mempunyai spesifikasi sebagai berikut: 
- Voltage/Frekuensi : $220 \mathrm{~V} / 50 \mathrm{~Hz}$

- Daya Output Motor : $375 \mathrm{~W}$

- Daya Input Motor : 0,65 kW

- Panjang pipa hisap : $40 \mathrm{~m}$

- Daya dorong maksimal: $60 \mathrm{~m}$

- Kapasitas

: $25 \mathrm{ltr} / \mathrm{min}$

- Pipa Hisap, $\varnothing$

: 1,25 inchi

- Pipa tekan, $\varnothing$

: 1 inchi

- Pipa dorong, $\varnothing$

: 1 inchi

Hasil pengukuran menggunakan pompa ini didapatkan volume air di dalam wadah air sebanyak 140 liter dan waktu yang diperlukan untuk pengujian 3 menit, melalui persamaan (1) maka diperoleh debitnya 46,7 l/mnt atau 0,778 l/s. Dengan merujuk dokumen paten yang berjudul Mesin Pencampur Pupuk Irigasi untuk Tanaman Sayuran yang mampu menghasilkan debit $4000 \mathrm{l} / \mathrm{h}$ mampu mengairi 0,25 ha (Balai Besar Pengembangan Mekanisasi Pertanian, 2012), maka alat pencampur pupuk hasil rancangan dapat mengairi lahan sayuran seluas 1,75 ha

Pada pipa lateral 1 dan lateral 2 terdapat venturimeter, keduanya berfungsi menghisap cairan nutrisi dari dalam wadah drigen 4 liter. Larutan nutrisi terhisap secara vertikal dalam waktu 3 menit dari masing-masing venturimeter terrendah $191 \mathrm{ml}$ hingga $468 \mathrm{ml}$, karena satu unit alat fertigasi terdapat dua venturimeter maka cairan nutrisi yang dihisap $383 \mathrm{ml}$ - 935 ml. Hasil perhitungan debit aliran cairan nutrisi untuk ketinggian hisap $44 \mathrm{~cm}, 52 \mathrm{~cm}$ dan $79 \mathrm{~cm}$ berturut-turut sebesar $5,19 \mathrm{ml} / \mathrm{s}, 4,31 \mathrm{ml} / \mathrm{s}$ dan $2,13 \mathrm{ml} / \mathrm{s}$.

\subsubsection{Hasil Uji Kinerja Alat}

Pengujian alat fertigasi yang dengan desain rangkaian seri mengalami kendala dimana tekanan air yang terdapat di dalam rangkaian lateral ke 2 terlalu rendah hingga larutan nutrisi tidak dapat terangkut. Telah diusahakan untuk menghindari kehilangan tekanan, pada saat pengujian dengan melakukan perombakan dalam rancangan dan dengan cara mengatur bukaan kran, namun tetap saja tidak dapat menarik larutan nutrisi dari dalam wadah, maka desain alat fertigasi rangkaian seri tidak dapat layak untuk dilanjutkan.

Uji kinerja alat fertigasi dengan desain rangkaian pararel dapat bekerja baik. Pengujian alat dilakukan dengan cara mengatur bukaan kran dilateral 1 dan lateral 2 sebesar $30^{\circ}, 45^{\circ}, 60^{\circ}$, $90^{\circ}$ dengan waktu uji 3 menit, dan diulang 3 kali. Kran pada pipa utama sebelum dan sesudah venturimeter pada kondisi terbuka, sedangkan kran bypass pada keadaan tertutup. Data besarnya tekanan yang terukur pada setiap manometer disajikan pada Tabel 2.

Pada pengujian bukaan kran $30^{\circ}$ didapatkan ratarata tekanan pada manometer $\mathrm{M} 1=1,93 \mathrm{bar}$, pada M2 dan M3 (sebelum air memasuki venturimeter ) menunjukan angka 0,90 bar dan 0,97 bar,

Tabel 1. Dimensi Alat Fertigasi Hasil Rancangan

\begin{tabular}{lr}
\hline Struktur alat & Ukuran (cm) \\
\hline a) Kerangka penopang & 171 \\
panjang & 78 \\
lebar atas & 113 \\
lebar bawah & 131 \\
tinggi & \\
b) Ukuran rangkaian alat & 9 \\
Tinggi dari lantai: & 109 \\
Tinggi pompa & 11 \\
Tinggi pipa penghisap & \\
Tinggi manometer dari pipa & 66 \\
Panjang: & 44 \\
panjang pipa pompa & 56 \\
panjang pipa pompa lanjutan & 168 \\
panjang pipa pompa lanjutan & 80 \\
panjang pipa utama & 80 \\
panjang lateral 1 & \\
panjang lateral 2 & \\
\hline
\end{tabular}


kemudian tekanan pada manometer M4 dan M5 (setelah venturimeter) keduanya menunjukkan angka 0,5 bar, sedangkan tekanan akhir ditunjukan pada M6 sebesar 1,77 bar.

Sedangkan pengujian bukaan kran $45^{\circ}$ didapatkan rata-rata tekanan pada manometer M1 = 1,93 bar, pada M2 dan M3 (sebelum air memasuki venturimeter ) menunjukan angka 0,97 bar dan 0,93 bar, kemudian tekanan pada manometer M4 dan M5 (setelah venturimeter) keduanya menunjukkan angka 0,50 bar, sedangkan tekanan akhir ditunjukan pada M6 sebesar 1,73 bar.

Berikutnya pengujian bukaan kran $60^{\circ}$ didapatkan rata-rata tekanan pada manometer M1 = 1,87 bar, pada M2 dan M3 (sebelum air memasuki venturimeter ) menunjukan angka 0,90 bar dan 0,83 bar, kemudian tekanan pada manometer M4 dan M5 (setelah venturimeter) keduanya menunjukkan angka 0,40 bar, sedangkan tekanan akhir ditunjukan pada M6 sebesar 1,63 bar.

Pada pengujian bukaan kran penuh $\left(90^{\circ}\right)$ didapatkan rata-rata tekanan pada manometer M1 = 1,87 bar, pada M2 dan M3 (sebelum air memasuki venturimeter ) menunjukan angka 0,90 bar dan 0,83 bar, kemudian tekanan pada manometer M4 dan M5 (setelah venturimeter) keduanya menunjukkan angka 0,40 bar, sedangkan tekanan akhir ditunjukan pada M6 sebesar 1,69 bar. Besarnya tekanan yang melalui lateral 1 (Gambar 3a), mulai pipa utama sebelum percabanagan (M1), setelah percabangan sebelum venturi (M2), setelah venturi (M4), hingga kembali tergabung pada pipa utama (M6) pada setiap tingkat bukaan kran disajikan pada Gambar 3. Sedangkan besarnya tekanan yang

Tabel 2. Data Pengukuran dari Setiap Manometer pada Pipa Utama dan Dua Pipa Lateral

\begin{tabular}{|c|c|c|c|c|c|}
\hline \multirow{2}{*}{ Bukaan kran } & \multirow{2}{*}{ Lateral } & \multicolumn{4}{|c|}{ Tekanan manometer (bar) } \\
\hline & & M1 & M2 / M3 & M4 / M5 & M6 \\
\hline \multirow{2}{*}{$30 \mathrm{deg}$} & Lateral 1 & \multirow{2}{*}{1,93} & 0,90 & 0,50 & \multirow{2}{*}{1,77} \\
\hline & Lateral 2 & & 0,97 & 0,50 & \\
\hline \multirow{2}{*}{$45 \mathrm{deg}$} & Lateral 1 & \multirow{2}{*}{1,93} & 0,97 & 0,50 & \multirow{2}{*}{1,73} \\
\hline & Lateral 2 & & 0,93 & 0,50 & \\
\hline \multirow[b]{2}{*}{$60 \mathrm{deg}$} & Lateral 1 & \multirow{2}{*}{1,87} & 0,90 & 0,40 & \multirow{2}{*}{1,63} \\
\hline & Lateral 2 & & 0,83 & 0,40 & \\
\hline \multirow{2}{*}{90 deg } & Lateral 1 & \multirow{2}{*}{1,87} & 0,90 & 0,40 & \multirow{2}{*}{1,63} \\
\hline & Lateral 2 & & 0,83 & 0,40 & \\
\hline \multirow{3}{*}{ Rataan } & Lateral 1 & \multirow{3}{*}{1,90} & 0,92 & 0,45 & \multirow{3}{*}{1,69} \\
\hline & Lateral 2 & & 0,89 & 0,45 & \\
\hline & Total & & 0,90 & 0,45 & \\
\hline
\end{tabular}

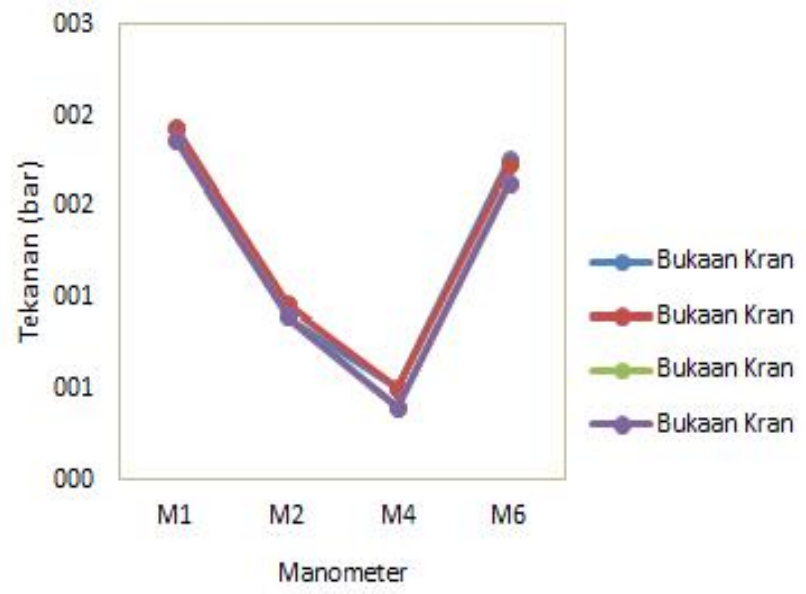

(a)

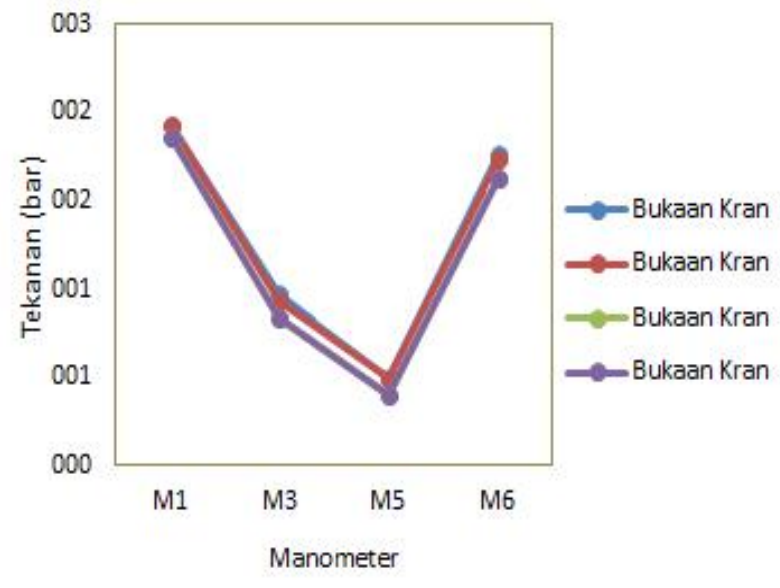

(b)

Gambar 3. Perubahan Tekanan pada (a) Lateral 1 dan (b) Lateral 2 
melalui pipa lateral 2, mulai pipa utama sebelum percabanagan (M1), setelah percabangan sebelum venturi (M3), setelah venturi (M5), hingga kembali tergabung pada pipa utama (M6) pada setiap tingkat bukaan kran disajikan pada Gambar 3b. Karakteristik perubahan tekanan yang melintasi pipa lateral 2 dan lateral 2 mempunyai tipikal yang sama, seperti disajikan pada Gambar 4.

Perbedaan tekanan antara sebelum dan sesudah venturimeter, merupakan tekanan yang berfungsi untuk menghisap cairan nutrisi dari wadah hingga lubang masukan ke venturi. Nilai perbedaan tekanan ini nilai hampir sama untuk semua tingkatan bukaan keran, hal ini menunjukan kemampuan hisap nutrisi juga hampir sama pada semua tingkatan bukaan kran dari $30^{\circ}, 45^{\circ}, 60^{\circ}$, dan $90^{\circ}$.

Pengujian juga melakukan pengamatan terhadap kemampuan hisap cairan nutrisi pada tiga tingkatan ketinggian hisap yaitu $44 \mathrm{~cm}, 52 \mathrm{~cm}$ dan $79 \mathrm{~cm}$. Variasi dari tiga tingkatan ketinggian hisap tersebut diuji pada empat tingkatan bukaan kran yaitu $30^{\circ}, 45^{\circ}, 60^{\circ}$, dan $90^{\circ}$. Pengukuran volume cairan nutrisi yang terhisap dilakukan setiap satuan percobaan selama 3 menit Jumlah volume cairan nutrisi terhisap dari kedua venturi yang terdapat pada kedua pipa lateral hampir identik, hal ini sesuai dengan selisih tekanan antara sebelum dan sesudah venturi dari kedua pipa lateral tersebut. Oleh karena itu penyajian volume, debit dan persentase cairan nutrisi yang terhisap merupakan jumlah dari dua venturi. Jumlah larutan nutrisi yang terhisap dari dua venturi selama 3 menit pada setiap bukaan kran dan ketinggian hisap nutrisi, disajikan pada Tabel 3.

Pada jarak hisap vertikal $44 \mathrm{~cm}$ dari batas bawah venturimeter ke batas permukaan larutan di dalam drigen, didapatkan data jumlah larutan nutrisi yang terhisap rata-rata $920 \mathrm{ml}$ pada bukaan kran $30^{\circ}, 930 \mathrm{ml}$ pada bukaan kran $45^{\circ}$, $940 \mathrm{ml}$ pada bukaan kran $60^{\circ}$, dan $950 \mathrm{ml}$ pada bukaan kran $90^{\circ}$, hingga didapatkan rata-rata total sebesar $935 \mathrm{ml}$.

Pada jarak hisap vertikal $52 \mathrm{~cm}$ dari batas bawah venturimeter ke batas permukaan larutan di dalam drigen, didapatkan data jumlah larutan nutrisi yang terhisap rata-rata $750 \mathrm{ml}$ pada bukaan kran $30^{\circ}, 790 \mathrm{ml}$ pada bukaan kran $45^{\circ}$, $790 \mathrm{ml}$ pada bukaan kran $60^{\circ}$, dan $770 \mathrm{ml}$ pada bukaan kran $90^{\circ}$, hingga didapatkan rata-rata total sebesar $775 \mathrm{ml}$.

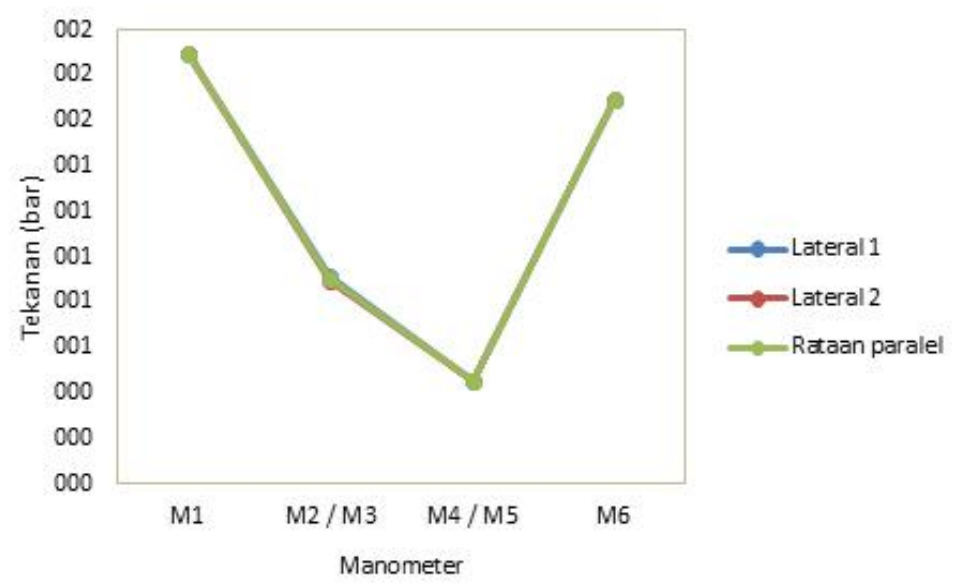

Gambar 4. Perubahan Tekanan Kedua Lateral Paralel

Tabel 3. Jumlah Larutan Nutrisi yang Terhisap dari Dua Venturi Selama 3 Menit pada Setiap Bukaan Kran dan Ketinggian Hisap Nutrisi (ml)

\begin{tabular}{cccccc}
\hline Ketinggian Hisap & \multicolumn{5}{c}{ Debit Larutan Nutrisi (ml) } \\
\cline { 2 - 6 } Larutan Nutrisi & $\mathbf{3 0 ~ \mathbf { d e g }}$ & $\mathbf{4 5} \mathbf{~ d e g}$ & $\mathbf{6 0 ~ d e g}$ & $\mathbf{9 0 ~ d e g}$ & Rata-rata \\
\hline $\mathrm{H}=44 \mathrm{~cm}$ & 920 & 930 & 940 & 950 & 935 \\
$\mathrm{H}=52 \mathrm{~cm}$ & 750 & 790 & 790 & 770 & 775 \\
$\mathrm{H}=79 \mathrm{~cm}$ & 370 & 390 & 390 & 380 & 383 \\
\hline
\end{tabular}


Pada jarak hisap vertikal $79 \mathrm{~cm}$ dari batas bawah venturimeter ke batas permukaan larutan di dalam drigen, didapatkan data jumlah larutan nutrisi yang terhisap rata-rata $370 \mathrm{ml}$ pada bukaan kran $30^{\circ}, 390 \mathrm{ml}$ pada bukaan kran $45^{\circ}$, $390 \mathrm{ml}$ pada bukaan kran $60^{\circ}$, dan $380 \mathrm{ml}$ pada bukaan kran $90^{\circ}$, hingga didapatkan rata-rata total sebesar $383 \mathrm{ml}$. Jumlah volume cairan nutrisi terhisap dari kedua venturi yang terdapat pada kedua pipa lateral dan pada setiap tingkatan bukaan kran hampir sama, hal ini juga sesuai dengan selisih tekanan antara sebelum dan sesudah venturi pada setiap tingkatan bukaan kran dari kedua pipa lateral tersebut. Dengan demikian perbedaan jumlah cairan nutrisi yang terhisap sangat bergantung pada ketinggian hisap cairan nutrisi. Semakin besar jarak hisap vertikal maka semakin rendah jumlah nutrisi yang dapat diangkut memalui venturimeter. Dengan demikian hubungan antara jumlah larutan nutrisi yang dapat terangkut melalui venturimeter dengan jarak hisap vertikal adalah berbanding terbalik.
Dari data jumlah larutan nutrisi yang terhisap dari dua venturi selama 3 menit pada setiap bukaan kran dan ketinggian hisap nutrisi pada Tabel 3, dapat diperoleh debit larutan nutrisi yang terhisap pada setiap bukaan kran dan ketinggian hisap nutrisi yang disajikan pada Tabel 4. Pada Tabel 4 nilai debit pada setiap tingkatan bukaan ktran hampir sama tetapi nilai debit terlihat berbanding terbalik dengan ketinggian hisap. Hal ini sejalan dengan hasil penelitian Solichin dan Kustono (2003) dimana antara debit dan tekanan berbanding lurus.

Selanjutnya dengan debit pompa sebesar 0,778 l/s dapat diperoleh besarnya rasio nutrisi yang terkandung dalam air irigasi, yang dapat dilihat pada Tabel 5. Penyajian secara grafik dari rasio nutrisi yang terlarut pada setiap bukaan kran dan ketinggian hisap nutrisi $(\% \mathrm{~V} / \mathrm{V})$ dapat dilihat pada Gambar 5. Besarnya rasio nutrisi yang terlarut pada ketinggian hisap $44 \mathrm{~cm}, 52 \mathrm{~cm}$ dan $79 \mathrm{~cm}$ masing-masing $0,67 \%, 0,55 \%$ dan 0,27 $\%(\mathrm{~V} / \mathrm{V})$. Dengan demikian rasio nutrisi yang

Tabel 4. Debit Larutan Nutrisi yang Terhisap pada Setiap Bukaan Kran dan Ketinggian Hisap Nutrisi $(\mathrm{ml} / \mathrm{s})$

\begin{tabular}{cccccc}
\hline Ketinggian Hisap & \multicolumn{5}{c}{ Debit Larutan Nutrisi (ml/s) } \\
\cline { 2 - 6 } Larutan Nutrisi & $\mathbf{3 0 ~ d e g}$ & $\mathbf{4 5} \mathbf{~ d e g}$ & $\mathbf{6 0 ~ d e g}$ & $\mathbf{9 0 ~ d e g}$ & Rata-rata \\
\hline $\mathrm{H}=44 \mathrm{~cm}$ & 5,11 & 5,17 & 5,22 & 5,28 & 5,19 \\
$\mathrm{H}=52 \mathrm{~cm}$ & 4,17 & 4,39 & 4,39 & 4,28 & 4,31 \\
$\mathrm{H}=79 \mathrm{~cm}$ & 2,06 & 2,17 & 2,17 & 2,11 & 2,13 \\
\hline
\end{tabular}

Tabel 5. Rasio Nutrisi yang Terlarut pada Setiap Bukaan Kran dan Ketinggian Hisap Nutrisi (\% V/V)

\begin{tabular}{cccccc}
\hline Ketinggian Hisap & \multicolumn{5}{c}{ Rasio nutrisi terlarut (\% V/V) } \\
\cline { 2 - 6 } Larutan Nutrisi & $\mathbf{3 0} \mathbf{~ d e g}$ & $\mathbf{4 5} \mathbf{~ d e g}$ & $\mathbf{6 0 ~ d e g}$ & $\mathbf{9 0 ~ d e g}$ & Rata-rata \\
\hline $\mathrm{H}=44 \mathrm{~cm}$ & 0,66 & 0,66 & 0,67 & 0,68 & 0,67 \\
$\mathrm{H}=52 \mathrm{~cm}$ & 0,54 & 0,56 & 0,56 & 0,55 & 0,55 \\
$\mathrm{H}=79 \mathrm{~cm}$ & 0,26 & 0,28 & 0,28 & 0,27 & 0,27 \\
\hline
\end{tabular}

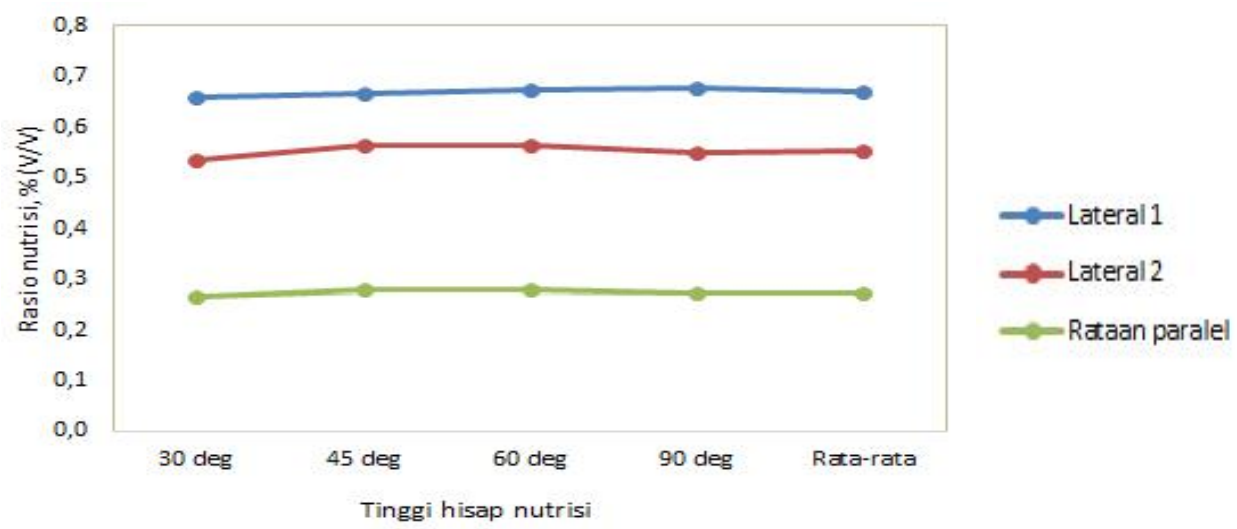

Gambar 5. Rasio Nutrisi yang Terhisap dari Setiap Ketinggian Hisap 
terlarut dalam air irigasi sangat bergantung pada ketinggian hisap, semakin besar ketinggian hisap maka rasio nutrisi yang terlarut semakin kecil. Rasio nutrisi tidak mengalami perubahan terhadap perubahan tingkat bukaan kran pada pipa utama, hal ini sejalan dengan selisih tekanan sebelum dan sesudah venturi yang nilainya hampir sama.

\section{KESIMPULAN DAN SARAN}

\subsection{Kesimpulan}

Alat fertigasi hasil rancangan dengan menggunakan dua venturimeter, dengan debit air irigasi 0,778 l/s, dan debit keluaran nutrisi 5,19 $-2,13 \mathrm{ml} / \mathrm{s}$, atau rasio larutan nutrisi $0,67-0,27$ $\%(\mathrm{~V} / \mathrm{V})$, mampu menghisap cairan nutrisi pada jarak vertikal $44 \mathrm{~cm}, 52 \mathrm{~cm}$, dan $79 \mathrm{~cm}$ dan selama 3 menit masing-masing sebesar $955 \mathrm{ml}, 775 \mathrm{ml}$, dan $383 \mathrm{ml}$. Nilai rasio nutrisi terhadap air irigasi sesuai jarak hisap vertikal $44 \mathrm{~cm}, 52 \mathrm{~cm}$, dan 79 cm masing-masing 0,67 \%, 0,55 \% dan 0,27 \% $(\mathrm{V} / \mathrm{V})$. Besarnya rasio nitrisi berbanding terbalik dengan ketinggian hisap cairan nutrisi, namun tidak terpengatuh oleh tingkat bukaan kran.

\subsection{Saran}

Desain alat fertigasi banyak macamnya dan dimungkinkan untuk menggunakan berbagai ukuran venturimeter dan tekanan suplai air, maka untuk mendapatkan dosis yang tepat perlu menguji respon venturimeter terhadap tekanan.

\section{DAFTAR PUSTAKA}

Al-Ayubi, M.S., Dzulkiflih, Rahmawati, E. 2015. Perancangan Dan Penerapan Aparatus Pengukuran Debit Air Dengan Menggunakan Venturimeter Dan Water Flow Sensor. Jurnal Inovasi Fisika Indonesia 4 (2) : 21 - 26.

Balai Besar Pengembangan Mekanisasi Pertanian. 2012. Mesin Pencampur Pupuk Irigasi (Fertigasi) untuk Tanaman Sayuran, Paten Indonesia, ID-P0031485B, 03 Agustus 2012.
Direktorat Pengelolaan Air. 2010. Pedoman Teknis Pengembangan Irigasi Bertekanan. Direktorat Jendera Pengelolaan Lahan dan Air, Departemen Pertanian. Jakarta.

Djunaedi, A.F. dan Wicaksono, M.A. 2013. Penyuluhan Dan Pembuatan Pupuk Organik Unmeningkatkan Produksi Hasil Panen. Jurnal Inovasi dan Kewirausahaan 2 (3): 212-216

Madhu, K.S., dan Bheemarao W. 2016. Design, Analysis (CFD) and Development of fertilizers Injection System for Irigation. International journal of Innovative Reserch and Science, Enginering and Technology (IJIRSET)5 (4)

Naswir, Hardjoamidjojo S., Pandjaitan, N.H dan Pawitan, H. 2009. Efektivitas Sistem Fertigasi Mikro untuk Lahan Sempit. Jurnal Forum Pascasarjana 32 (1):45-54

Saptomo, S.K., Chadirin, Y., Setiawan, B.I., dan Sofiyudin, H.A. 2012. Peningkatan Efisiensi Air Irigasi dengan Introduksi sistem Otomatis pada Sistem Irigasi di Lahan Produksi Pangan. Prosiding Seminar Perhimpunan Ahli Teknik Hidraulik Indonesia pada Pertemuan Ilmiah Tahunan ke 29, Bandung 19-21 Oktober 2012

Saputro, N.A., Setyawati, E.R., Pauliz Budi Hastuti, P.B. 2017. Pengaruh Konsentrasi Urin Kambing Fermentasi Dan Komposisi Media Tanam Terhadap Pertumbuhan Bibit Kelapa Sawit Di Pre Nursery. Jurnal AGROMAST 2(1)

Solichin, S. dan Kustono, D. 2003. Model Hubungan Antara Debit Dengan Beda Tekanan Pada Venturi untuk Aliran Fluida Inkompresibel. Jurnal Teknologi dan Kejuruan 26 (2) 